\title{
ANALISIS LENDUTAN STRUKTUR PERKERASAN KAKU AKIBAT PENGARUH KADAR AIR TANAH DASAR
}

(Analysis of Deflection on Rigid Pavement as a Result of Subgrade Water Content)

\author{
Hendra Wahyu, Suherman Sulaiman, Mujiman \\ Jurusan Teknik Sipil Politeknik Negeri Bandung \\ Email: hendrawahyu10@gmail.com
}

\begin{abstract}
The research attempts to find the deflection on a concrete slab that functions as a layer on top of a rigid pavement, the strain occurring on the pulling part as an effect of subgrade water, and the effects of static quasi loads in the middle of the concrete slab.

The research adopted the experimental method with a testing object of concrete slab with a size of $1.0 \times 1.0 \times 0,1$ $m$ placed on top of lean concrete layer and subgrade with the size of $1.0 \times 1.0 \times 0,035 \mathrm{~m}$ and $1.0 \times 1.0 \times 0.4 \mathrm{~m}$, respectively. Quasi-static loads were placed upon 3 (three) variations of tested objects. Variation 1 is the placing of loads on top of a concrete slab with $30 \%$ water content of the subgrade dry weight; variation 2 is the placing of loads on top of a concrete slab with $40 \%$ water content of the subgrade dry weight; and variation 3 the placing of loads on top of a concrete slab with 50\% water content of the subgrade dry weight. The findings show that the carrying capacity of the concrete slab decreases. Th maximum carrying capacities of the concrete slab were $82.5 \mathrm{kN}, 62.33 \mathrm{kN}$, and $30.06 \mathrm{kN}$ for variation 1, variation 2, and variation 3, respectively.
\end{abstract}

Keywords: Concrete slab, deflection, water content.

\section{PENDAHULUAN}

Seiring dioperasikannya perkerasan kaku, kerusakan pada struktur perkerasan pun mulai terjadi. Penyebab kerusakan pada perkerasan kaku tersebut bervariasi, diantaranya beban yang berlebih, mutu beton yang tidak memenuhi standar perencanaan, dan tanah dasar yang terganggu akibat masuknya air melalui celah, retakan pelat beton atau bahu jalan. Dari beberapa penyebab kerusakan yang terjadi, pada penelitian ini fokus membahas lendutan pada pelat beton, dimana kondisi tanah dasar dipengaruhi oleh kadar air yang berbeda.

Beban yang bekerja pada pelat beton mengakibatkan terjadinya lendutan [1]. Beban yang berada pada sisi ujung pelat menimbulkan lendutan yang paling besar. Dengan memperbesar nilai modulus reaksi tanah gabungan, atau juga sering disebut sebagai nilai modulus reaksi tanah efektif, maka besaran lendutan berkurang. Nilai modulus reaksi tanah dasar gabungan sangat berpengaruh terhadap besar nilai CBR [2]. Dengan menggunakan pendekatan hubungan grafik antara CBR dan modulus reaksi tanah dasar, hasil penelitian tersebut memperlihatkan bahwa semakin besar nilai CBR, maka nilai modulus reaksi tanah dasar semakin meningkat. Sebaliknya, nilai CBR rendah, maka nilai modulus reaksi tanah dasar menurun, sehingga terjadi lendutan pada pelat beton saat beban bekerja. Besaran lendutan yang terjadi sangat dipengaruhi oleh besaran nilai modulus reaksi tanah dasar (Kv) [3]. Besaran nilai modulus reaksi tanah sangat dipengaruhi oleh besaran nilai CBR. Semakin tinggi nilai CBR, maka semakin besar nilai modulus reaksi tanah dasar.
Selanjutnya, penelitian tentang pengaruh perubahan kadar air terhadap sifat teknis tanah lanau kelempungan dengan variabel kadar air pada tanah dasar ditemukan bahwa semakin besar kadar air pada tanah dasar, maka semakin rendah nilai $\mathrm{CBR}$ [4].

Berdasarkan penjelasan di atas, jelas bahwa penelitian sebelumnya fokus pada perilaku lendutan pada perkerasan kaku di atas tanah dasar yang tidak terganggu oleh faktor kadar air dan karakteristik tanah dasar saja. Penelitian Analisis Lendutan Struktur Perkerasan Kaku Akibat Pengaruh Kadar Tanah Tanah Dasar ini menambahkan kadar air pada tanah tanah dasar diharapkan dapat diketahui perbandingan besaran lendutan yang terjadi akibat pengaruh air tanah dasar dan beban yang bekerja pada perkerasan kaku, sehingga dapat dijadikan pertimbangan dalam perencanaan dan tindakan pencegahan penyebab kerusakan pada perkerasan kaku.

\section{DASAR TEORI}

\section{Modulus Reaksi Tanah Gabungan}

Pada lapisan tanah dasar yang di atasnya diberi lapisan beton tipis lean concrete, maka nilai modulus reaksi tanah dihitung untuk gabungan antara tanah dasar dan lean concrete [5]. Besaran nilai modulus reaksi tanah gabungan dapat dihitung dengan rumus sebagai berikut: 
$\ln k_{c 1}=-2,807+0,1253\left(\ln D_{S B}\right)^{2}+$

$1,062\left(\ln M_{R 1}\right)+0,1282\left(\ln D_{S B}\right)\left(\ln E_{S B}\right)-$

$0,4114\left(\ln D_{S B}\right)-0,0581\left(\ln E_{S B}\right)$

$-0,1317\left(\ln D_{S B}\right)\left(\ln M_{R 1}\right)$

Dimana:

$\mathrm{K}_{\mathrm{c}}$ : Modulus reaksi tanah gabungan

$\mathrm{D}_{\mathrm{sb}}$ : Tebal lean concrete $(\mathrm{m})$

$\mathrm{M}_{\mathrm{R}}$ : Modulus elastis tanah tanah dasar $(\mathrm{kN})$

$\mathrm{E}_{\mathrm{sb}}$ : Modulus Elastis beton lean concrete

Berdasarkan teori Asphalt Institute, besaran nilai modulus resilient $\left(\mathrm{M}_{\mathrm{R}}\right)$ yaitu

$$
\mathrm{M}_{\mathrm{R}}=0,3 \times \mathrm{CBR} \quad(\mathrm{Mpa})
$$

\section{Hitung Lendutan}

Pelat beton diasumsikan sebagai balok di atas fondasi elastis yang tergantung dari nilai fleksibilitas balok $(\lambda)[6]$ :

$$
\lambda=\sqrt{\frac{K B}{4 E I}} \quad\left(\mathrm{~m}^{-1}\right)
$$

Dimana:

$\lambda=$ Fleksibilitasbalok di atastanah $\left(\mathrm{m}^{-1}\right)$

$\mathrm{E}=$ Modulus Elastisbalok $(\mathrm{kN} / \mathrm{m} 2)$

$\mathrm{I}=$ MomenInersiaBalok $\left(\mathrm{m}^{4}\right)$

$\mathrm{K}=$ Modulus reaksitanahdasar $(\mathrm{kN} / \mathrm{m} 2)$

Untuk menghitung besaran lendutan perkerasan kaku di atas tanah yang elastis dengan panjang terbatas yang dibebani beban terpusat pada tengah pelat (Gambar 1), digunakan persamaan dari teori balok pada fondasi elastik:

$$
\begin{aligned}
& \delta=\frac{Q}{2 K} \frac{1}{\sinh \lambda l+\sin \lambda l} \mathrm{x} \\
& \left\{\begin{array}{c}
\cosh \lambda(l-x)+\cos \lambda x \cosh \lambda(l-x) \\
-\sinh \lambda x \sin \lambda(l-x)+\sin \lambda x \sin \lambda(l-x) \\
+2 \cosh \lambda x \cos \lambda x
\end{array}\right\}
\end{aligned}
$$

$\mathrm{Q}$

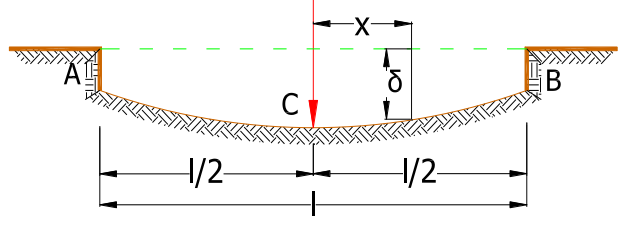

Gambar 1. Balok terhingga yang dibebani beban titik pada tengah bentang (Hetenyi, 1974)

\section{METODE PENELITIAN}

\subsection{Alat}

Alat-alat yang perlu disiapkan untuk penelitian yaitu:

1. Alat untuk pengujian CBR laboratorium dan CBR lapangan tanah dasar.

2. Alat untuk pengujian mutu beton, yaitu untuk pengujian kuat tekan beton.

3. Alat sensor, sebagai berikut:

a. Alat Linier Variable Differential Tranducer (LVDT) untuk mengetahui besaran lendutan pada benda uji dengan dimensi.

b. Load Cell untuk membaca beban dari hydraulic jack secara elektrik dengan hasil baca yang lebih akurat. Hydraulic jack untuk memberikan tekanan beban yang diinginkanpadaperkerasanbeton.

c. Data logger dan Komputer untuk melihat hasil uji lapangan secara visual dan sebagai data perekam hasil uji, dilengkapi dengan memori data untuk menyimpan data secara real time.

\subsection{Pengujian Material}

Material uji terdiri dari tanah sebagai tanah dasar dan material beton yang terdiri dari agregat halus, agregat kasar bahan pengikat semen, dan air. Tanah dasar diambil dari Km. 78 tol Purbaleunyi, yang merupakan salah satu titik di mana pumping seringkali terjadi.

\subsubsection{Material Tanah Dasar}

\section{a.Pengujian Laboratorium}

Sebelum dilakukan pengujian lapangan, perlu dilakukan pengujian laboratorium terlebih dahulu terhadap material tanah dasar untuk memperoleh data karakteristik tanah yang ada. Hasil pengujian menghasilkan data diantaranya yaitu, nilai CBR, berat jenis tanah, nilai Indeks plastis, nilai liquid limit, plastis limit, kadar air eksisting, dan kadar air optimum. Hasil pengujian laboratorium menjadi dasar untuk menentukan variasi pada pengujian di lapangan.

\section{b.Pengujian CBR Lapangan}

Untuk memperoleh besarnya daya dukung tanah, maka dilakukan uji CBR lapangan dengan ukuran benda uji 1000x1000x400 mm yang dibuat sebanyak 3 variasi, yaitu kadar air $30 \%$, kadar air 40\%, dan kadar air 50\%. Untuk memperoleh keseragaman daya dukung tanah, maka pengujian CBR dilakukan di tiga titik yaitu, tengah, tepi kiri, dan tepi kanan tanah dasar (Gambar 2). Acuan untuk menentukan kekuatan tanah dengan Uji CBR sesuai dengan SNI-1744-1989. 

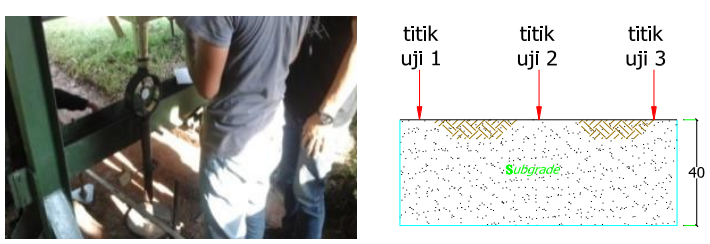

Gambar 2. Pengujian CBR Lapangan

\subsubsection{Uji beban pada pelat beton}

Benda uji beton terdiri dari lean concrete dengan ukuran 1000 x 1000 × $35 \mathrm{~mm}$ dan pelat beton dengan ukuran 1000 x 1000 x 100 yang dibuat masing-masing sebanyak 3 buah. Pada variasi 1 pelat beton dan lapisan lean concrete diletakkan di atas tanah dasar dengan kadar air sebesar $30 \%$. Pada variasi 2 dan variasi 3, lapisan struktur perkerasan yang sama digunakan, namun masingmasing variasi kadar air tanah dasar berbeda, yaitu berturut-turut sebesar $40 \%$ dan 50\% (Gambar 3). Pada penelitian ini dilakukan uji pembebanan statik di tengah pelat untuk menganalisis perilaku lendutan akibat pengaruh kadar air pada tanah dasar.
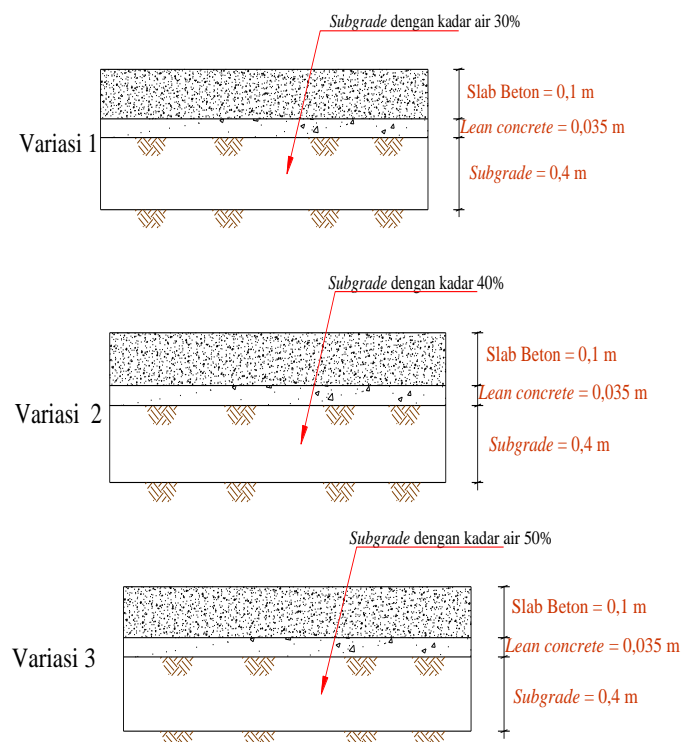

Gambar 3.Variasi pemodelan benda uji

Pengujian dilakukan di lingkungan laboratorium Teknik Sipil Politeknik Negeri Bandung. Tanah dasar yang diuji diambil dari tanah dasar jalan Tol Purbaleunyi Km. 78B, dimana lokasi tersebut perkerasan kakunya mengalami kerusakan berupa pumping. Hasil pengujian laboratorium diperoleh pada variasi 1 kondisi optimum $\left(\mathrm{w}_{\mathrm{opt}}\right)=30 \%, \mathrm{PL}=$ $4,17 \%, \mathrm{LL}=60,73 \%, \mathrm{PI}=19,6 \%$, berat jenis $\left(\mathrm{G}_{\mathrm{s}}\right)=$ 2,60; dan kandungan butiran tanah terbesar yaitu lanau sebesar $(M)=69,70 \%$. Pelat beton memiliki ukuran 1000 × $1000 \times 100 \mathrm{~mm}$. Kuat tekan beton fc' 25,2 Mpa. Lean concrete berukuran 1000 x 1000 x $35 \mathrm{~mm}$. Kuat tekan beton fc' 8,4 Mpa. Modulus elastis (E) masing-masing pelat beton dan lean cocncrete dihitung sebesar $=4700 \sqrt{f c^{\prime}}$.
Beban pelat dilakukan dengan hydraulic jack yang ditopang dengan rangka baja. Posisi beban ditempatkan di tengah pelat beton yang diberi landasan pelat baja yang kaku dan dilapisi karet dengan panjang $18 \mathrm{~cm}$ dan lebar $8 \mathrm{~cm}$.

\section{HASIL DAN PEMBAHASAN 4.1 Pengujian tanah}

Pada penelitian ini, terdapat 3 (tiga) variasi tanah dasar dengan penambahan persenatase kadar air berdasarkan berat kering tanah, yaitu variasi 1 dengan kadar air tanah sebesar $30 \%$, variasi 2 dengan kadar air tanah sebesar $40 \%$, dan variasi 3 dengan kadar air tanah sebesar 50\%. Pengujian CBR unsoaked dilakukan skala laboratorium untuk memperoleh batasan untuk pemadatan dan pengujian CBR di lapangan. Hasil uji CBR Masing-masing variasi diberikan beban kuasi statik secara terpusat sebesar $2 \mathrm{kN}, 5 \mathrm{kN}$, dan $10 \mathrm{kN}$ dan mencapai keruntuhan berturut-turut untuk variasi 1 , variasi 2, dan variasi 3 .

Untuk mengetahui besaran lendutan, dipasang 3 buah LVDT di atas pelat, yaitu di tengah, di tepi kiri, dan di tepi kanan pelat (Gambar 4). Setup uji pembebanan pelat beton (Gambar 5).

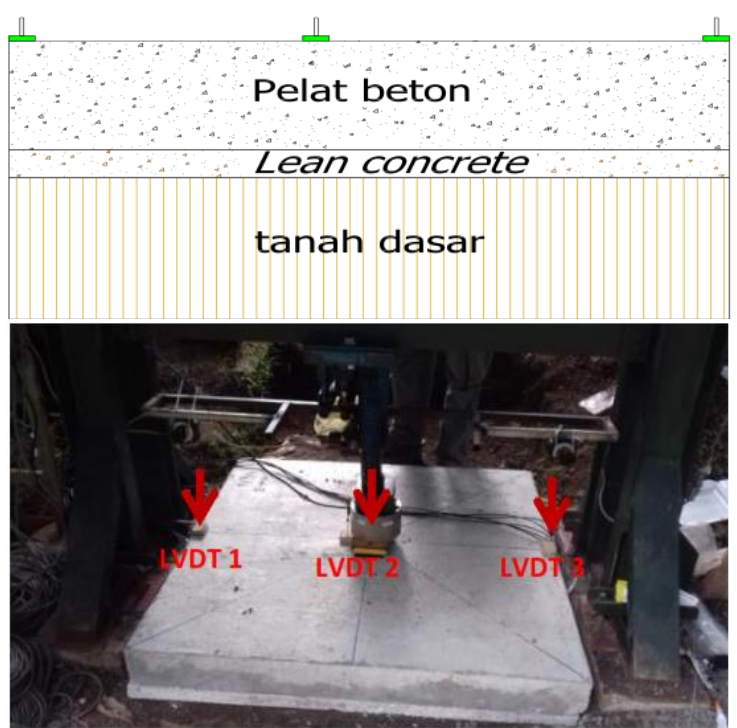

Gambar 4. Posisi sensor LVDT pada permukaan pelat beton 


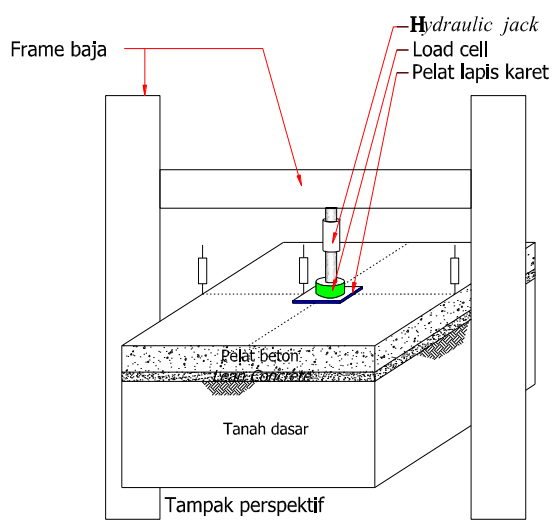

Gambar 5.Set up uji pembebanan pelat beton pada kadar air tanah variasi 1 , variasi 2 , dan variasi 3

Hasil pengujian laboratorium dan lapangan ditunjukkan pada Tabel 1. Nilai modulus reaksi tanah gabungan $\left(\mathrm{k}_{\mathrm{c}}\right)$ dihitung menggunakan persamaan (1), besarnya nilai reaksi kc bergantung pada nilai modulus resilien, yaitu sebesar 10,3 CBR (Asphalt Institute,1982). Hasil perhitungan sebagaimana ditunjukkan pada Tabel 2. Semakin tinggi nilai CBR, maka semakin tinggi pula nilai modulus resilien, dan sebaliknya.

Tabel 1. Hasil uji CBR laboratorium dan lapangan pada 3 (tiga) variasi tanah

\begin{tabular}{c|c|c|c|c}
\hline \multirow{2}{*}{ No } & Variasi & $\begin{array}{c}\text { Kadar } \\
\text { Air } \\
(\%)\end{array}$ & $\begin{array}{c}\text { CBR } \\
\text { Laboratorium } \\
(\%)\end{array}$ & $\begin{array}{c}\text { CBR } \\
\text { Rerata } \\
\text { Lapanga } \\
\mathrm{n} \\
(\%)\end{array}$ \\
\hline 1 & Variasi 1 & $\begin{array}{c}30 \\
(\mathrm{OMC})\end{array}$ & 25,57 & 24,57 \\
\hline 2 & Variasi 2 & 40 & 5,73 & 4,61 \\
\hline 3 & Variasi 3 & 50 & 0,26 & 0,25 \\
\hline
\end{tabular}

Tabel 2. Hasil perhitungan ModulusResilientanah

\begin{tabular}{c|c}
\multicolumn{2}{c}{$\left(\mathrm{M}_{\mathrm{R}}\right)$} \\
\hline $\begin{array}{c}\text { CBR } \\
(\%)\end{array}$ & $\begin{array}{c}\mathrm{M}_{\mathrm{R}}=10,3 \\
\mathrm{CBR} \\
(\mathrm{MPa})\end{array}$ \\
\hline 24,57 & 253,07 \\
\hline 4,61 & 47,52 \\
\hline 0,25 & 2,56 \\
\hline
\end{tabular}

\subsection{Pengujian Lendutan dengan variasi kadar sebesar air $30 \%$, $40 \%$, dan $50 \%$}

Posisi beban ditempatkan di tengah pelat beton yang diberi landasan pelat baja dan dilapisi karet dengan panjang $18 \mathrm{~cm}$ dan lebar $8 \mathrm{~cm}$. Masingmasing variasi diberikan beban kuasi statik secara terpusat sampai pelat beton mengalami keruntuhan, sebagaimana ditunjukkan pada Gambar 6.

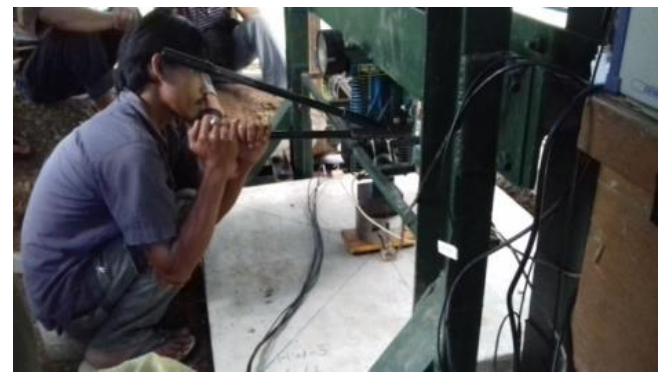

Gambar 6. Pemberian beban pada pelat beton

Pengujian pembebanan pada pelat beton terjadi keruntuhan sebagaimana ditunjukkan seperti pada Gambar 7 dan hasil pengujian disajikan pada Gambar 8.
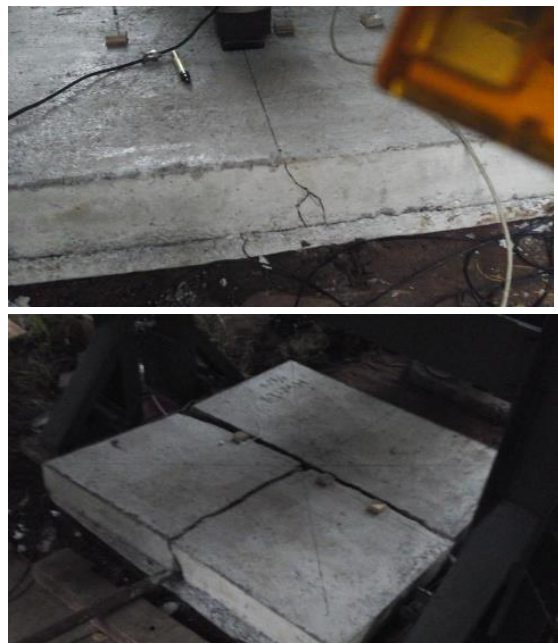

Gambar 7. Pelat beton runtuh pada beban maksimal

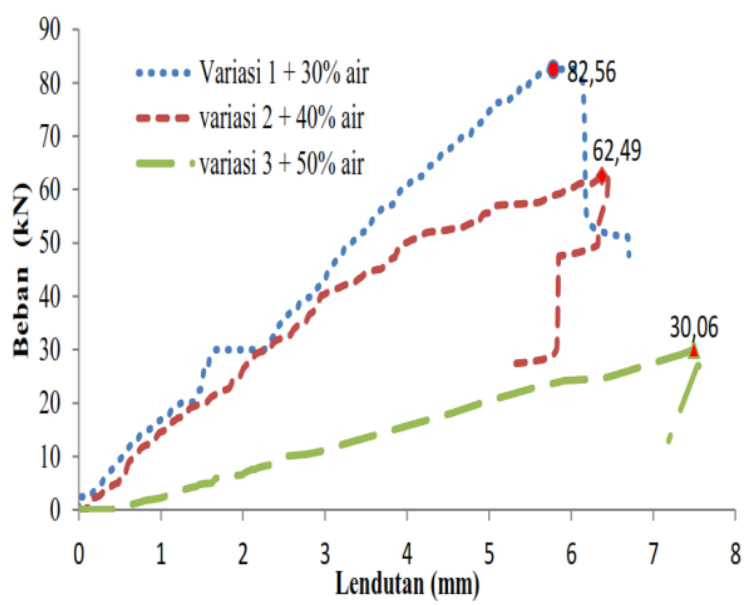

Gambar 8. Hubungan antara lendutan dengan beban pada pelat beton 
Hasilnya memperlihatkan bahwa reaksi tanah dasar gabungan sangat mempengaruhi nilai lendutan yang terjadi pada pelat beton, jika variasi 1 dibandingkan dengan variasi 2 dan variasi3. Nilai lendutan meningkat berbanding dengan bertambahnya kadar air tanah dasar (Tabel 3). Semakin kecil modulus reaksi tanah $\left(\mathrm{M}_{\mathrm{R}}\right)$ pada persamaan (2), maka semakin kecil daya dukung yang dapat diberikan, sehingga sebagian besar tekanan beban ditahan langsung oleh pelat beton.

Selain itu, daya dukung pelat beton juga tergantung dari nilai fleksibilitas balok $(\lambda)$ yang dihitung dengan menggunakan persamaan (3). Efeknya adalah lendutan semakin besar. Untuk menetukan besaran lendutan secara teoritis digunakan persamaan (4). Sebagaimana ditunjukkan pada Tabel 4.

Tabel 3. Lendutan hasil eksperimen pelat beton

\begin{tabular}{|c|c|c|c|c|c|}
\hline $\begin{array}{c}\text { Variasi } \\
\text { benda uji }\end{array}$ & $\begin{array}{c}\text { Beban } \\
\text { maksimal } \\
(\mathrm{kN})\end{array}$ & $\begin{array}{c}\text { LVDT1 } \\
(\mathrm{mm})\end{array}$ & $\begin{array}{c}\text { LVDT2 } \\
(\mathrm{mm})\end{array}$ & $\begin{array}{c}\text { LVDT3 } \\
(\mathrm{mm})\end{array}$ & $\begin{array}{c}\text { Lendutan efektif } \\
(\mathrm{mm}) \\
(\text { LVDT 2) } \\
\text { (LVDDT }\end{array}$ \\
\hline Variasi 1 & 82,56 & 0,132 & 6,0990 & 0,00031 & 6,03 \\
\hline Variasi 2 & 62,49 & 0,0038 & 6,4489 & 0,00136 & 6,44 \\
\hline Variasi 3 & 30,06 & 0,00721 & 7,5713 & 0,01192 & 7,56 \\
\hline
\end{tabular}

Tabel 4. Lendutan hasil eksperimen dan perhitungan

\begin{tabular}{|c|c|c|c|c|c|}
\hline $\begin{array}{c}\text { Variasi } \\
\text { tanah dasar }\end{array}$ & $\begin{array}{c}\text { Modulus } \\
\text { reaksi } \\
\text { gabungan } \\
(\mathrm{kN} / \mathrm{m} 3)\end{array}$ & $\begin{array}{c}\text { Beban } \\
(\mathrm{kN})\end{array}$ & $\begin{array}{c}\text { Lendutan }(\delta) \\
\text { Perhitungan } \\
(\mathrm{mm})\end{array}$ & $\begin{array}{c}\text { Lendutan }(\delta) \\
\text { eksperimen } \\
(\mathrm{mm})\end{array}$ & $\begin{array}{c}\text { Selisih } \\
(\%)\end{array}$ \\
\hline $\begin{array}{c}\text { Variasi 1+ } \\
\text { air tanah } \\
30 \%\end{array}$ & $13,052,75$ & 82,56 & 6,37 & 6,03 & 5,64 \\
\hline $\begin{array}{c}\text { Variasi 2+ } \\
\text { air tanah } \\
40 \%\end{array}$ & 2371,64 & 62,49 & 6,88 & 6,44 & 6,83 \\
\hline $\begin{array}{c}\text { Variasi 3+ } \\
\text { air tanah } \\
50 \%\end{array}$ & 120,81 & 30,06 & 8,03 & 7,56 & 6,22 \\
\hline
\end{tabular}

Dapat disimpulkan bahwa pengaruh modulus reaksi tanah sangat besar terhadap kinerja perkerasan kaku. Jika daya dukung tanah dasar menurun, maka lendutan pada pelat beton meningkat.

\section{PEMBAHASAN}

Dari hasil analisis tiap variasi kadar air tanah, diketahui bahwa peningkatan kadar air pada tanah dasar menyebabkan penurunan nilai CBR, yang kemudian mempengaruhi nilai modulus reaksi tanah dasar gabungan $\left(\mathrm{k}_{\mathrm{c}}\right)$. Dari seluruh hasil uji pada (Tabel 3), terlihat bahwa nilai lendutan hasil pengamatan dengan perhitungan fondasi elastis tidak jauh berbeda. Ini menunjukan teori tersebut efektif digunakan untuk memprediksi lendutan pada balok di atas fondasi elastis.

Perbedaan antara nilai lendutan experimen dan empiris tidak terlalu besar yaitu sebesar 5,64\%, $6,83 \%$, dan $6,22 \%$ berturut-turut untuk variasi 1 , variasi 2 , dan variasi 3 .

Hasil penelitian juga menunjukkan penurunan daya dukung pelat beton seiring meningkatnya kadar air tanah dan nilai lendutan yang terjadi. Berturut-turut untuk variasi 1, variasi 2 , dan variasi 3 daya dukung tanah sebesar $82,56 \mathrm{kN}$; 62, $49 \mathrm{kN}$; dan 30,06 kN. Ini menunjukan besarnya pengaruh kadar air pada tanah dasar terhadap kinerja pelat beton di atasnya.

Dari hasil pengamatan, nilai lendutan meningkat seiring bertambahnya kadar air pada tanah dasar. Pada variasi 1 dengan beban sebesar $82,56 \mathrm{kN}$, diperoleh nilai lendutan sebesar 6,37; selanjutnya pada variasi 2 dengan beban sebesar $62,33 \mathrm{kN}$, diperoleh lendutan sebesar $6,44 \mathrm{~mm}$; kemudian untuk variasi 3 dengan beban sebesar $30,064 \mathrm{kN}$ diperoleh lendutan sebesar 7,56 $\mathrm{mm}$.

\section{KESIMPULAN DAN SARAN 6.1 Kesimpulan}

1. Perbedaan nilai lendutan antara pengamatan dengan perhitungan relatif tidak jauh berbeda. Selisih nilai lendutan sebesar $5,64 \%, 6,83 \%$, dan 6,22\% berturut-turut untuk masing-masing variasi.

2. Daya dukung pelat beton maksimum menurun akibat peningkatan kadar air tanah dasar sebesar 82,56 kN, 62,49 kN dan 30,06 kN berturut-turut untuk kadar air tanah sebesar $30 \%, 40 \%$ dan $50 \%$.

3. Terjadi keruntuhan pada pelat beton sebelum mencapai beban yang seharusnya, yaitu beban pada kondisi air optimum yaitu sebesar 82,56 $\mathrm{kN}$. Ini menunjukan bahwa pelat beton akan lebih cepat mengalami kerusakan. 


\subsection{Saran}

1. Perlu dilakukan penelitian terhadap lendutan, regangan, dan besarnya transfer beban dengan melakukan pengujian beban kuasi statik pada jenis perkerasan beton semen bersambung dengan tulangan. Setidaknya ada 3 (tiga) pelat beton yang disambung dengan

menggunakan dowel/ ruji.

2. Perlu dilakukan pengujian pelat beton skala penuh dengan Accelerated Pavement Testing (APT) sebagai simulasi kendaraan di atas pelat beton bersambung, minimal 3 (tiga) pelat beton dengan variasi kadar air tanah dasar, sehingga diperoleh respon struktur yang sebenarnya.

\section{DAFTAR PUSTAKA}

[1] Hardiyatmo. Metoda Hitungan Pelat dengan Menggunakan Modulus Reaksi Tanah Dasar Ekivalen untuk Struktur Pelat Fleksibel. Dinamika TEKNIK SIPIL 9(2), hlm. 149 - 154, 2009.

[2 Rahmawati,Y.Zaika,,E.A.Suryo,.Perbandingan Mudulus Reaksi Tanah Sungrade berdasarkan uji CBR Terhadap Hasil Uji Beban Pelat.2014.

[3] Diana.Perbandingan Analisis Lendutan Pelat dengan Menggunakan Metoda Beam on Elastic Foundation (BoEF) and Finite Element Method (FEM), 2011.

[4] Sismiani. Pengaruh Perubahan Kadar Air terhadap Sifat Teknis Tanah Lanau Kelempungan. Tesis. UGM, Yogyakarta.2013.

[5] AASHTO, 1993.

[6] Hetenyi. Beams on Elastic Foundation. Michigan: The University of Michigan, 1974 